\title{
Acceptance of pandemic influenza A (H1N1) 2009 vaccine among health care workers, Thailand
}

\author{
C Chotpitayasunondh*, S Patrasuwan, M Prontri, S Poiynok \\ From International Conference on Prevention \& Infection Control (ICPIC 2011) \\ Geneva, Switzerland. 29 June - 2 July 2011
}

\section{Introduction / objectives}

To identify factors associated with the acceptance of the pandemic influenza A (H1N1) 2009 vaccine among health care workers (HCWs).

\section{Methods}

From March 1 to 31, 2009, a self-administered structured questionnaire survey was conducted among 700 HCWs to examine their knowledge, attitudes and practices toward the pandemic influenza vaccination.

\section{Results}

The surveyed participants were composed of physician $8.5 \%$, nurse $35 \%$, and paramedic staff $56.5 \%$. The response rate was $97.6 \%$. Although $84 \%$ of the respondents regarded this vaccine as being beneficial, only $60.1 \%$ were willing to be vaccinated. The most common reason for refusal of vaccination was concern about the potential side effects of vaccine (29\%). The most common source of vaccine information was broadcast media (67.8\%), mainly TV and radio. Most respondents (72\%) considered vaccination as the most important means for influenza control and prevention. Univariate analysis indicated that HCWs who regarded this vaccine as being safe and/or beneficial were 7 times more likely to agree to vaccinate compared to those who believed otherwise (RR: 7.08; 95\% CI : 4.70-10.67). In contrast, those who had heard about vaccine adverse event from broadcast media were less likely to do so (RR: 0.77 ; $95 \%$ CI: 0.66-0.89). Furthermore, receiving vaccine safety information from health personnel was significantly associated with increased vaccine acceptance (RR: 2.07; 95\% CI: 1.68-2.54).

Nursing, Royal Irrigation Hospital, Srinakharinwirot U., Nontaburi, Thailand

\section{Conclusion}

Effective control and prevention of disease faces a major challenge posed by the nominal level of influenza vaccine acceptance among HCWs. In order to achieve an enhanced level of influenza vaccination acceptance, the provision of up-to-date and correct vaccine information to both HCWs and the mass media is of essentiality.

\section{Disclosure of interest}

None declared.

Published: 29 June 2011

\section{doi:10.1186/1753-6561-5-S6-P83}

Cite this article as: Chotpitayasunondh et al: Acceptance of pandemic influenza A (H1N1) 2009 vaccine among health care workers, Thailand. BMC Proceedings 2011 5(Suppl 6):P83.
Submit your next manuscript to BioMed Central and take full advantage of:

- Convenient online submission

- Thorough peer review

- No space constraints or color figure charges

- Immediate publication on acceptance

- Inclusion in PubMed, CAS, Scopus and Google Scholar

- Research which is freely available for redistribution
C Biomed Central

\section{Biomed Central}

(c) 2011 Chotpitayasunondh et al; licensee BioMed Central Ltd. This is an open access article distributed under the terms of the Creative Commons Attribution License (http://creativecommons.org/licenses/by/2.0), which permits unrestricted use, distribution, and reproduction in any medium, provided the original work is properly cited. 